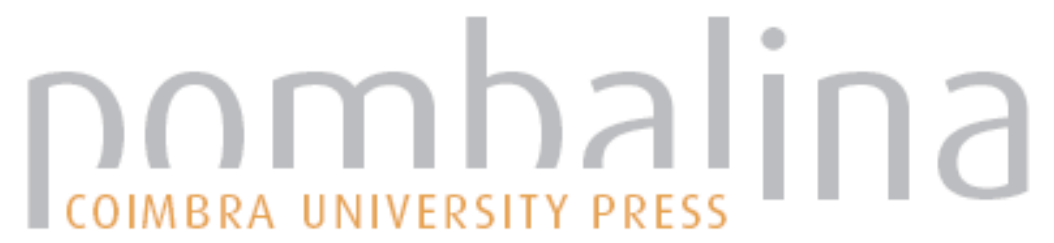

(8)

\section{Mobile application based on a physical model to calculate Acceptable Safety Distance}

\begin{tabular}{|c|c|}
\hline Autor(es): & $\begin{array}{l}\text { Bisgambiglia, Paul-Antoine; Franceschini, Romain; Chatelon, François- } \\
\text { Joseph; Rossi, Jean-Louis; Bisgambiglia, Paul Antoine }\end{array}$ \\
\hline Publicado por: & Imprensa da Universidade de Coimbra \\
\hline $\begin{array}{l}\text { URL } \\
\text { persistente: }\end{array}$ & URI:http://hdl.handle.net/10316.2/34233 \\
\hline DOI: & DOI:http://dx.doi.org/10.14195/978-989-26-0884-6_157 \\
\hline Accessed : & 26-Apr-2023 11:51:52 \\
\hline
\end{tabular}

A navegação consulta e descarregamento dos títulos inseridos nas Bibliotecas Digitais UC Digitalis, UC Pombalina e UC Impactum, pressupõem a aceitação plena e sem reservas dos Termos e Condições de Uso destas Bibliotecas Digitais, disponíveis em https://digitalis.uc.pt/pt-pt/termos.

Conforme exposto nos referidos Termos e Condições de Uso, o descarregamento de títulos de acesso restrito requer uma licença válida de autorização devendo o utilizador aceder ao(s) documento(s) a partir de um endereço de IP da instituição detentora da supramencionada licença.

Ao utilizador é apenas permitido o descarregamento para uso pessoal, pelo que o emprego do(s) título(s) descarregado(s) para outro fim, designadamente comercial, carece de autorização do respetivo autor ou editor da obra.

Na medida em que todas as obras da UC Digitalis se encontram protegidas pelo Código do Direito de Autor e Direitos Conexos e demais legislação aplicável, toda a cópia, parcial ou total, deste documento, nos casos em que é legalmente admitida, deverá conter ou fazer-se acompanhar por este aviso.

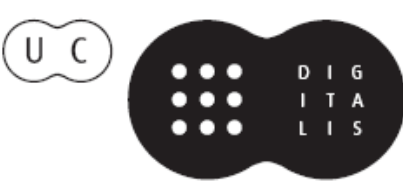




\section{ADVANCES IN}

Forest Fire

\section{RESEARCH}

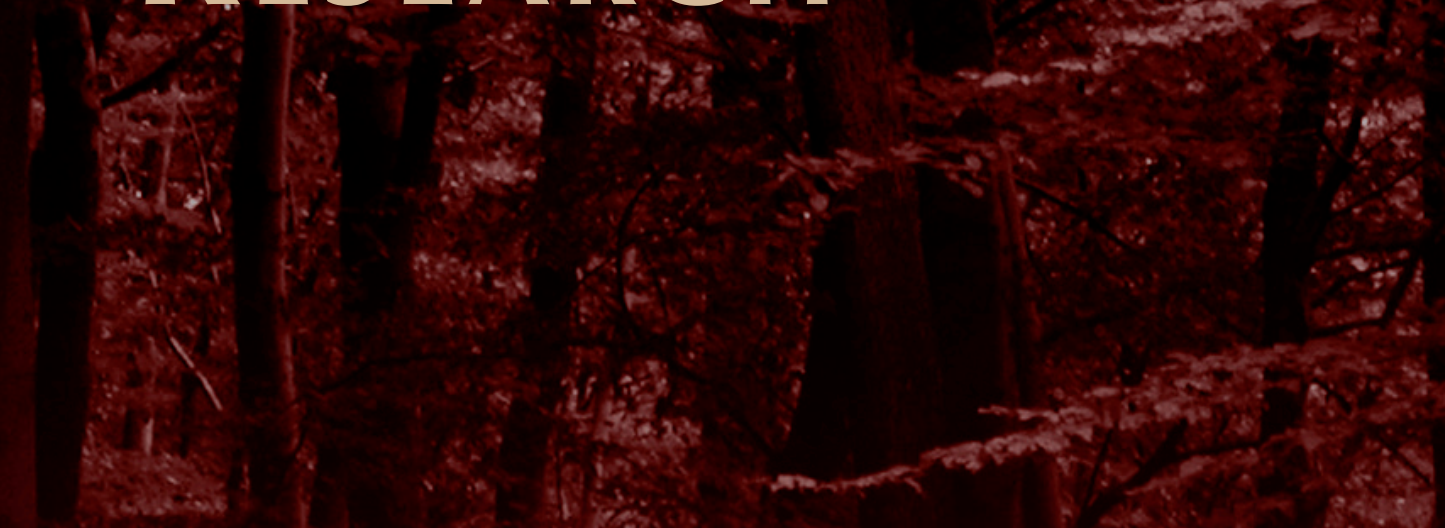

\section{DOMINGOS XAVIER VIEGAS}

\section{EDITOR}




\title{
Mobile application based on a physical model to calculate Acceptable Safety Distance
}

\author{
Paul-Antoine Bisgambiglia, Romain Franceschini, François-Joseph Chatelon, Jean-Louis Rossi, Paul \\ Antoine Bisgambiglia \\ ${ }^{a}$ University of Corsica - UMR SPE CNRS 6134, Campus Grimaldi bat PPDB 20250 Corti FRANCE. \\ bisgambiglia@univ-corse.fr, r.franceschini@univ-corse.fr, chatelon@univ-corse.fr, rossi@univ- \\ corse.fr, bisgambi@univ-corse.fr
}

\begin{abstract}
The purpose of this paper is to present a multidisciplinary work in order to propose a simple tool that forecasts fuelbreak safety zone sizes at the field scale. The main question associated with safety zones is determining the Acceptable Safety Distance (ASD) between the fire and firefighters required to prevent injury. This distance is usually set thanks to a general rule-of-thumb: it should be at least 4 times the maximum flame length. A common assumption consists in using an empirical relationship between fireline intensity and flame length. To quantify the fireline intensity, a closed physical model is applied. So, this Web Service uses a simulation framework based on Discrete EVent system Specification formalism (DEVS), a theoretical fire spreading model developed at the University of Corsica and a mobile application based on a Google SDK to display the results.
\end{abstract}

Keywords: Decision-Making Tool, Fire Model, Acceptable Safety Distance, ASD, Calculation Tool, DEVS, Mobile Application

\section{Introduction}

In the last few years the increasing influence of global warming on the environment has produced periods of drought which in turn have led to wildfires with devastating consequences. There is a growing need for firefighters to have decision-making tools. However, wildfires are so unpredictable that reducing their impact is still a complex task.

For several years, our fire team works on a models set. These different models are used to fire studies at different detail level, from fire laboratory to real forest fire. Recently, we developed some models to calculate the radiation rate and thereby compute the safety distances. In this work, we propose its integration into an online calculator: a Web Service. This web service will be interrogated by a mobile application to provide, as shown in Figure 1, an acceptable safety distance defined from a geographical area (GIS: Geographical Information System). These first results were introduced in Bisgambiglia et al., (2013).

Our tool has been designed with and for fire-fighters, to meet their needs. A mobile application is of great interest because it is portable and allows you to go on the ground.

In the first and second part, we present the physical model and the formalism used to implement it. Fire model is an analytical model based on University of Corsica's forest-fire propagation model. The model is called ASD for Acceptable Safety Distance. It is used to place the fire-fighters on the ground and assess the radiation rate to which they are exposed. The role of this system is twofold: (1) it calculates a safe distance for the prevention of forest fires. This distance is used to realize a fuel break by vegetation clearing; (2) it can also calculate a safety distance during the struggle. This distance informs the fire-fighters on the degree of heat in the vicinity of the fire front. This is an analytical model based on radiative heating, and a whole set of parameters, such as vegetation, meteorology, topography, etc. The flame model adopted is based on the radiant surface approach; it is generalized to take into account the effect of the fire front width. So far this model prediction has been compared against measured flame length of several experimental fires conducted at the field scale through a 
variety of natural vegetation in Corsican mountain region. The used formalism is called DEVS for Discrete EVent system Specification; it can be defined as multi-formalism and seen as a computational tool. DEVS is flexible, fast and open. In the field of Discrete Event Systems, many efforts have been devoted to develop appropriate tools to study, and model in a formal way the dynamics and the mechanisms of interaction of the natural systems. For several years the community is changing the DEVS formalism so that it can become a powerful tool for modelling complex systems. DEVS allows the reusing models through library already developed and also interconnecting of these models to compose heterogeneous models based on different formalisms.

In the third part, we will detail our software architecture. Including how the physical model has been modelled in our framework and what are the input data used. Then, we present how our DEVS models were migrated into a Web Service. Finally, we will detail the mobile application and its GUI (graphical user interface). Fire models have been implemented in a DEVS framework and coupled with a computational model of acceptable safety distance (ASD). The simulator is hosted on a Server to be queried remotely. At the start of the process, the user sends to the server a message with several positions. The server queries the Web Services to determine local parameters (slope, wind, etc.), and for each position compute the ASD. Finally, results are returned to the client for visualization in GIS. In the fourth part, we describe our results. In collaboration with fire-fighters, we defined five vegetation types. These types have been incorporated in the software. With the GUI, the user can choose a vegetation type. We propose a comparison of results based on different vegetation.

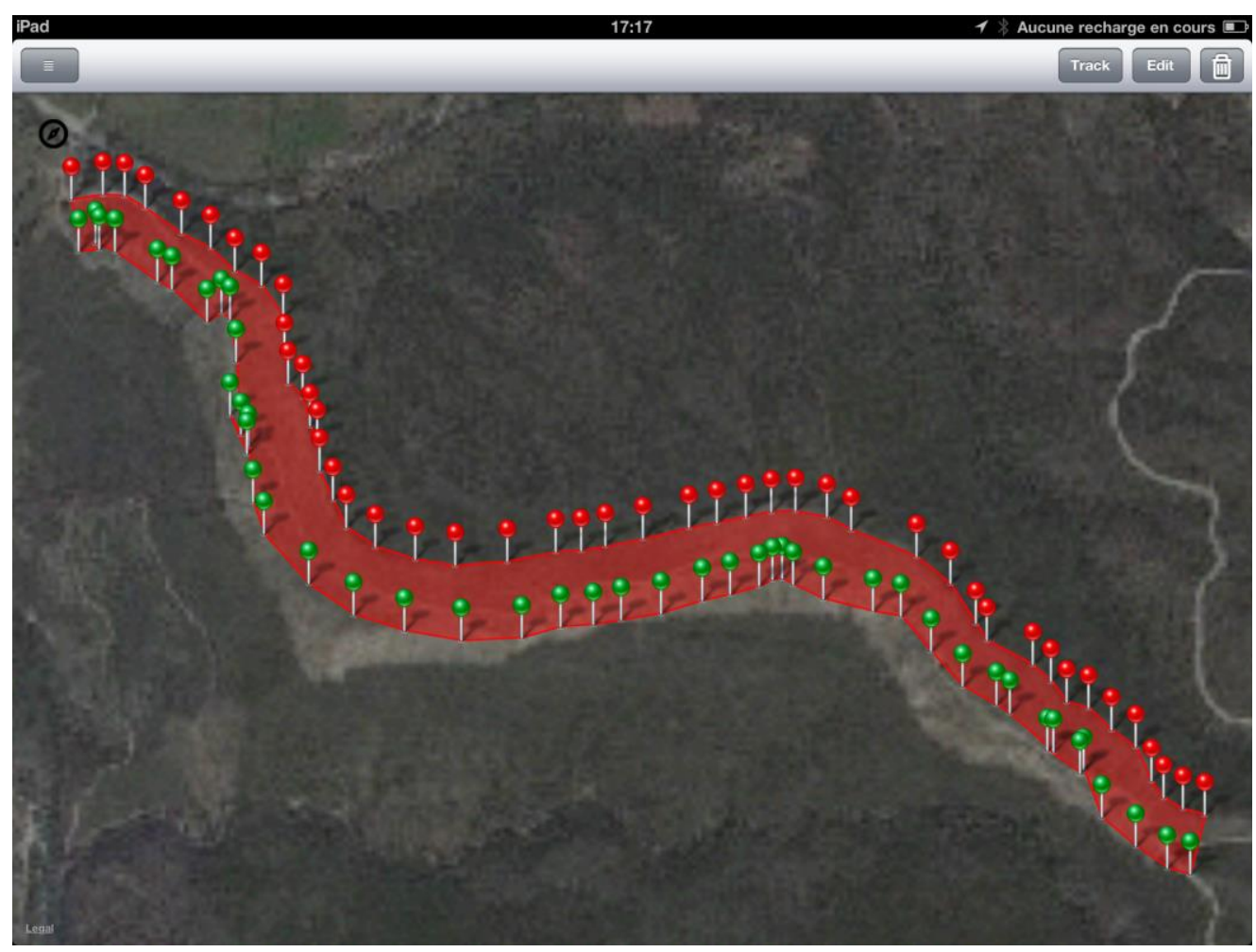

Figure 1. An overview of the application

\section{Physical Models}

The fire behaviour at the field scale is difficult to forecast. It is a tricky task because the physical processes of combustion and heat transfer and how they are influenced by meteorological conditions and the arrangement and type of fuel are complex. It belongs to the framework of strongly coupled non linear transport phenomena. The aim of this section is to propose a model of fire behaviour that is 
simple in concept and transparent to parameterize too. The main objective of this approach is to facilitate the use of existing vegetation models. A simplified surface fire spread model has been developed since 2007 at the University of Corsica in France. It has been tested on experiments carried out across fuel beds under slope and wind conditions at different field scales (Balbi et al., 2007; 2009; 2010). The two main equations of this physical 3D model are the following:

$$
\left.\begin{array}{l}
\tan \gamma=\tan \alpha+\frac{U_{n}}{u_{o}} \\
R=R_{o}+A R \frac{1+\sin \gamma-\cos \gamma}{1+\frac{R \cos \gamma}{r_{o}}}
\end{array}\right\}
$$

where $R$ is the fire spread rate across an equivalent homogeneous combustible medium and under slope and wind conditions. It is obtained by using a thermal balance assessment in the combustible zone downstream to the fire front. This relationship is the sum of two terms. The first one, $R_{o}$, evaluates the rate of spread under no wind and no slope (it represents the contribution of the radiation from the fuel burning particles area). The second one determines the radiant heat flux, which comes from the flame body. $\gamma$ represents the flame tilt angle. This angle is calculated using the local slope $(\alpha)$, the normal wind speed to the fire front $\left(U_{n}\right)$ and the upward gas velocity $\left(u_{o}\right)$. For an in-depth look at the determination of the rate of spread on the basis of this physical model, readers are encouraged to consult scales (Balbi et al., 2007; 2009; 2010).

A flame height submodel (Marcelli et al., 2011) is added to the simplified physical rate of spread model described by equation (1). As $h_{f}=l_{f} \cos \gamma$, where $l_{f}$ and $h_{f}$ denote the flame length and the flame height respectively, the flame length is expressed as

$$
I_{f}=\frac{2{ }_{0} r_{00} H_{v}}{B T^{4} \cos }
$$

where $\chi_{0}$ is a radiant factor (usually close to 0.3 ), $r_{00}$ is a universal rate of spread (ROS) factor (equal to $\left.2.5 \times 10^{-5}\right), \Delta H$ is the heat of combustion of the pyrolysis gases, $\rho_{v}$ is the fuel density, $v$ is the fuel absorption coefficient, $B$ is the Stefan-Boltzmann constant and $T_{f}$ is the mean flame temperature.

The main question associated with safety zones is determining the safety distance between the fire and firefighters required to prevent injury. This distance is usually set thanks to a general rule-of-thumb: it should be at least 4 times the maximum flame length (Butler and Cohen, 1998).

Fuelbreaks divide expanses of natural fuels into smaller units. Native vegetation on these strategically located wide strips of lands is modified so that fire burning into them can be more readily and safely controlled. Fuelbreak generally has a low-growing ground in order to protect the soil against erosion. But, fuelbreaks with safety zones providing safety for firefighting personnel and equipment under critical conditions should be wider than other parts of a fuel break. In selecting the widths of fuelbreaks safety zone, the forest manager must estimate the distance from the flame front necessary to prevent serious burns from radiated heat and direct ignition from radiation too. Green and Schimke (1971) estimated that the distances from the flame front necessary to prevent ignition from radiation are half of the distances considered necessary to prevent disabling burns. Hence, ignition from radiation across a wide fuelbreak should not be a problem. Assuming that the safety distance is in the center of the break, the total width of a fuelbreak safety zone must be equal to 2 times this distance.

\section{DEVS formalism}

Simulation is used to study fire evolution model. For example, the DEVS formalism has been used to model physical equations describing fire evolution; we can quote (Harzallah et al., 2008; Muzy et al. 2002; Bisgambiglia et al., 2006; Nader et al., 2011). This work focuses on the spreading aspect; our application aims to provide a safety distance. 
Since the 1970s, formal tasks have been performed to develop the theoretical foundations of modelling and simulating of discrete event systems. Discrete Event System Specification is an extension of the Moore machine formalisms which is used for modelling and analyzing general systems. Our interest focuses on the Discrete EVent system Specification formalism (Ziegler et al., 2000). DEVS provides a way of expressing discrete event models and a basis for an open distributed simulation environment. DEVS is universal for discrete event dynamic systems and is capable of representing a wide class of other dynamic systems. Universality for discrete event systems is defined as the ability to represent the behaviour of any discrete event model where represent and behaviour are appropriately defined. Concerning other dynamic system classes, DEVS can too simulate discrete time systems such as cellular automata and approximate, as closely as desired, differential equation systems. It also supports hierarchical modular construction and composition methodology. This bottom-up methodology keeps incremental complexity bounded and permits stage-wise verification since each coupled model build can be independently tested (Ziegler, 2005).

Major efforts have been made to adapt this formalism to various domains and situations as to study forest fire spreading (Harzallah et al., 2008; Innocenti et al., 2009; Muzy et al., 2005; Ntaimo et al., 2004; 2008; Nader et al., 2011). DEVS permits the modelling of causal and deterministic systems with two types of components. A DEVS model is either an Atomic (AM) or a Coupled (CM) model. An AM is a structure: $<\mathrm{X}, \mathrm{Y}, \mathrm{S}, \delta$ ext, $\delta$ int, $\lambda$, ta $>$ with

- $\mathrm{X}$ the set of external events,

- Y the set of output events,

- $\mathrm{S}$ the set of sequential states,

- $\delta$ ext: $\mathrm{Q} \times \mathrm{X} \rightarrow \mathrm{S}$ the external state transition function,

- where

- $\mathrm{Q}=\{(\mathrm{s}, \mathrm{e}) \mid \mathrm{s}$ in $\mathrm{S}, 0 \leq \mathrm{e} \leq \mathrm{ta}(\mathrm{s})$ and

- e is the elapsed time since the last state transition;

- $\quad \delta$ int $\mathrm{S} \rightarrow \mathrm{S}$ the internal state transition function;

- $\lambda: S \rightarrow Y$ the output function and

- $\quad \mathrm{ta}: \mathrm{S} \rightarrow \mathrm{R}+0 \rightarrow \infty$ the time advance function.

The AM describes the behaviour of the system. A atomic model is based on continuous time, inputs, outputs, states and functions (output, transition and lifetime of states). More complex models are constructed by connecting several atomic models in a hierarchical way. The interactions are created via the models' input and output ports, which favours modularity. A CM describes the composition of several DEVS sub-models, i.e AM or CM, it is described by the following formula: $\mathrm{CM}$ : $<\mathrm{X}_{\mathrm{M}}$; $\mathrm{Y}_{\mathrm{M}}$; $\mathrm{C}_{\mathrm{M}}$; EIC; EOC; IC; L >.

Where,

- $\mathrm{X}_{\mathrm{M}}$ : is the set of input ports;

- $\mathrm{Y}_{\mathrm{M}}$ : is the set of output ports;

- $\mathrm{C}_{\mathrm{M}}$ : is the list of models that composed the coupled model CM;

- EIC: is the set of the input couplings, which links the coupled model to its components;

- EOC: is the set of the output couplings, which links the components to the coupled model;

- IC: is the set of the internal couplings, which links the components to one another; and,

- $\mathrm{L}$ : is a list of priorities among components.

Many works have been proposed with the aim of mapping DEVS models in Web Services (Harzallah et al., 2008; Al-Zoubi and Wainer, 2009; Kim and Kang, 2005; Mittal et al., 2007; Wainer et al., 2008). Generally the aim of this works is twofold: (1) provide a service based on a DEVS model, and (2) extend the interoperability of DEVS formalism. We do not propose evolution at these levels, but simply the use of these concepts applied to another application field: the ASD calculation. Our approach is general because we want to use DEVS as a calculation tool. We also propose a comparison 
with a calculation program scientist and to equivalent results our environment is much more efficient. In addition, we can use DEVS to transform our calculation tool in online tool, and propose complete software architecture; efficient and adapted to the problem we were asked. That is to say: developing a tool for fuelbreak dimensioning.

\section{Application and software architecture}

In Bisgambiglia et al., (2013) the software architecture of our application was introduced. To summarize, our tool is fairly standard, it looks like in this work (Harzallah et al., 2008), and is based on DEVS-Ruby framework (Franceschini et al., 2014). We constructed a computational service as Web Service. Our Web Service is based on the DEVS formalism. It allows sending a safety distance, used to planning aid (fuelbreak) and prevention against forest fires. For our calculations, we need a certain number of data, and these data are either acquired locally, such as geolocation, or retrieved through other Web Services, such as ground slope. A main Web Service hosting a DEVS simulator to calculate the ASD. It can connect to another Web Services. The client sends data and displays the results. The Figure 2 describes this architecture. A main Web Service hosting a DEVS-Ruby simulator to calculate the ASD. It can connect to another Web Services. The client sends data and displays the results.

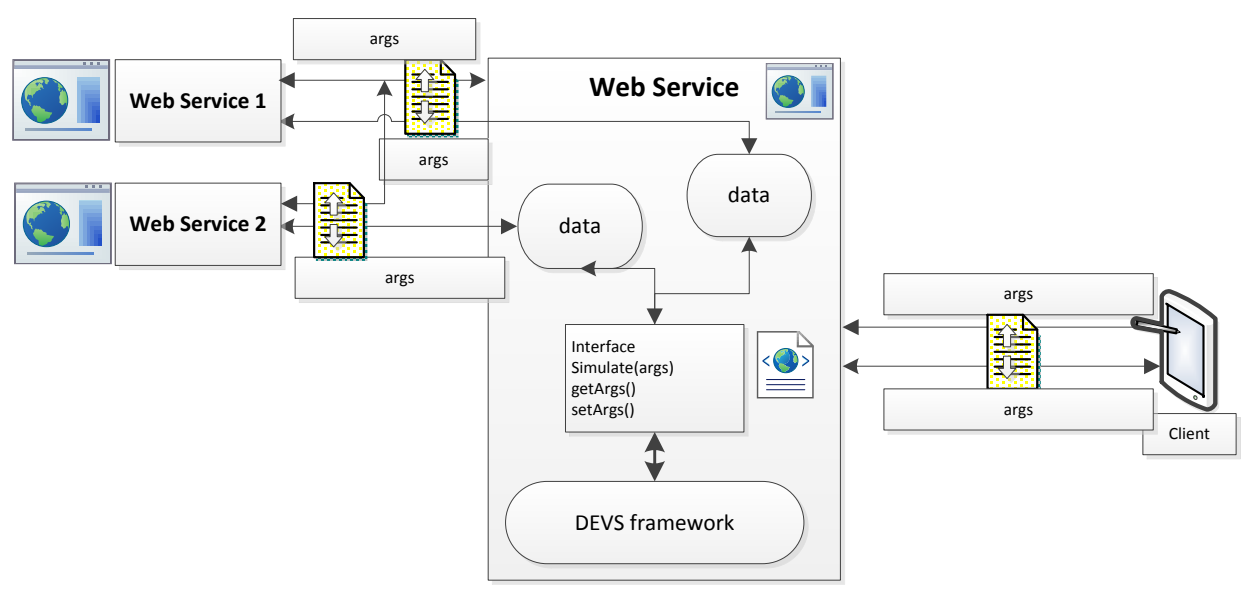

Figure 2. An overview of the overall approach.

The first step was to map the physical models to a DEVS models, then identify the major input parameters and finally transform the DEVS models to a DEVS Web Service. The computer architecture and the underlying technologies are described in Bisgambiglia et al. (2013).

Modelling the vegetation, denoted hereafter by fuel, is essential for the purpose of predicting the behaviour of a fire, either for fire danger rating system or fire spread model as well as to assess the impact of fire. Characterization of fuel particles is therefore required as an input to semi-empirical and physical fire behaviour models. The physical, chemical and thermal properties of fuel particles are assessed at the level of the individual particle or element

The different fuels characterization which are used in the mobile application in order to compare the values of the acceptable safety distances are presented in table 1. 
Table 1. Examples of fuel description in the Mediterranean

\begin{tabular}{cccccc}
\hline Fuel type & $\begin{array}{c}\text { Corsican tall } \\
\text { shrub }\end{array}$ & $\begin{array}{c}\text { Corsican } \\
\text { shrub }\end{array}$ & $\begin{array}{c}\text { Sardinian } \\
\text { shrub } \\
\text { type 1) }\end{array}$ & $\begin{array}{c}\text { Sardinian } \\
\text { shrub } \\
\text { type 2) }\end{array}$ & grassland \\
\hline Fuel Height (m) & 4 & 2 & 0.48 & 1.8 & 0.3 \\
\hline Fuel load (kg m-2) & 0.89 & 0.39 & 0.39 & 1.2 & 0.166 \\
\hline Fuel Moisture Content & 0.08 & 0.08 & 0.08 & 0.08 & 0.08 \\
\hline Surface area-to volume ratio & 5544 & 10200 & 2000 & 2400 & 11400 \\
\hline Heat of Combustion (kJ kg-1) & 19640 & 18620 & 18620 & 18620 & 18620 \\
\hline Fuel density (kg m-3) & 720 & 750 & 478 & 734 & 288 \\
\hline Specific Heat (J kg-1 K-1 & 1912 & 1900 & 1740 & 1820 & 1440 \\
\hline
\end{tabular}

\section{Results}

\subsection{Confrontation of the proposed physical model with field scale experiments}

This section deals with the comparison of thirteen experimental literature field shrubland fires with model results.

Experiments were located in mountain areas in the southern Cape Province of South Africa. Fires were conducted at two sites. The first site is situated in the Kogelberg State Forest $(110 \mathrm{~m}$ above the sea level). Detailed experiments description can be found in Van Wilgen et al. (1985).

Table 2. Observed and predicted flame lengths during the Kogelberg State Forest experiments.

\begin{tabular}{|c|c|c|c|c|c|c|c|c|}
\hline \multirow[b]{2}{*}{$\begin{array}{l}\text { Wind speed } \\
\left(\mathrm{m} \cdot \mathrm{s}^{-1}\right)\end{array}$} & \multicolumn{6}{|c|}{$\begin{array}{l}\text { Flame length } \\
(\mathrm{m})\end{array}$} & \multirow[t]{2}{*}{$\begin{array}{l}\text { NMSE } \\
(\%)\end{array}$} & \multirow[t]{2}{*}{$\begin{array}{l}F B \\
(-)\end{array}$} \\
\hline & 3.56 & 1.5 & 2.67 & 2.67 & 3.11 & 3.11 & & \\
\hline $\begin{array}{l}\text { Rate of spread } \\
\left(\mathrm{cm} \cdot \mathrm{s}^{-1}\right)\end{array}$ & 44 & 36 & 21 & 30 & 37 & 47 & & \\
\hline Observed & 3.2 & 2.4 & 2 & 4.3 & 3 & 4 & & \\
\hline Physical model & 4.15 & 2.11 & 3.47 & 3.48 & 4.23 & 3.99 & 7.9 & 0.13 \\
\hline Burrows (1994) & 15.39 & 12.12 & 10.10 & 15.9 & 20.52 & 17.97 & 326.3 & 1.31 \\
\hline Butler et al. (2004) & 7.33 & 5.96 & 5.09 & 7.55 & 9.41 & 8.39 & 80.1 & 0.80 \\
\hline Byram (1959) & 4.99 & 4.32 & 3.88 & 5.09 & 5.93 & 5.47 & 23.3 & 0.46 \\
\hline $\begin{array}{l}\text { Catchpole et al. } \\
\text { (1998) }\end{array}$ & 5.15 & 4.33 & 3.80 & 5.28 & 6.35 & 5.77 & 27.1 & 0.49 \\
\hline Clark (1983) & 5.65 & 4.15 & 3.29 & 5.90 & 8.19 & 6.90 & 45.3 & 0.55 \\
\hline $\begin{array}{l}\text { Fernandes et al. } \\
\text { (2009) }\end{array}$ & 6.15 & 5.20 & 4.57 & 6.30 & 7.54 & 6.87 & 48.6 & 0.65 \\
\hline $\begin{array}{l}\text { Fernandes et al. } \\
(2000)\end{array}$ & 3.11 & 2.70 & 2.43 & 3.17 & 3.69 & 3.41 & 4.06 & 0.006 \\
\hline Nelson (1980) & 4.09 & 3.50 & 3.11 & 4.18 & 4.94 & 4.53 & 9.57 & 0.27 \\
\hline $\begin{array}{l}\text { Nelson and Adkins } \\
\text { (1986) }\end{array}$ & 4.12 & 3.53 & 3.14 & 4.20 & 4.95 & 4.55 & 9.84 & 0.28 \\
\hline Van Wilgen (1986) & 4.80 & 4.09 & 3.62 & 4.90 & 5.81 & 5.32 & 20.1 & 0.42 \\
\hline Vega et al. (1998) & 7.54 & 6.47 & 5.76 & 7.70 & 9.07 & 8.33 & 82.6 & 0.82 \\
\hline
\end{tabular}


Table 3. Observed and predicted flame lengths during the Cederberg State Forest experiments.

\begin{tabular}{|c|c|c|c|c|c|c|c|c|c|c|}
\hline $\begin{array}{l}\text { Wind speed } \\
\left(\mathrm{m} \cdot \mathrm{s}^{-1}\right)\end{array}$ & 1.92 & 2.83 & 3.56 & 2.5 & 1.03 & 1.89 & 3.11 & 2.67 & & \\
\hline $\begin{array}{l}\text { Rate of spread } \\
\left(\mathrm{cm} \cdot \mathrm{s}^{-1}\right)\end{array}$ & 32 & 80 & 89 & 52 & 4 & 52 & 78 & 55 & & \\
\hline \multicolumn{9}{|c|}{$\begin{array}{l}\text { Flame length } \\
\text { (m) }\end{array}$} & $\begin{array}{c}\text { NMSE } \\
(\%)\end{array}$ & $\begin{array}{c}F B \\
(-)\end{array}$ \\
\hline Observed & 4 & 6 & 7 & 5 & 1.4 & 6.5 & 5 & 5 & & \\
\hline PM & 4.52 & 5.27 & 6.65 & 4.84 & 3.94 & 3.99 & 6.27 & 5.63 & 7.66 & 0.09 \\
\hline $\begin{array}{l}\text { Burrows } \\
\text { (1994) }\end{array}$ & 17.55 & 59.03 & 45.32 & 19.23 & 3.78 & 26.40 & 40.38 & 33.34 & 582.9 & 1.33 \\
\hline $\begin{array}{l}\text { Butler et al. } \\
\text { (2004) }\end{array}$ & 8.22 & 23.52 & 18.70 & 8.90 & 2.17 & 11.71 & 16.92 & 14.33 & 140.9 & 0.80 \\
\hline Byram (1959) & 5.4 & 11.15 & 9.52 & 5.70 & 2.15 & 6.89 & 8.88 & 7.92 & 20.7 & 0.35 \\
\hline $\begin{array}{l}\text { Catchpole et } \\
\text { al. (1998) }\end{array}$ & 5.67 & 13.69 & 11.30 & 6.06 & 1.86 & 7.63 & 10.39 & 9.04 & 39.26 & 0.43 \\
\hline Clark (1983) & 6.69 & 31.90 & 22.70 & 7.53 & 0.92 & 11.32 & 19.57 & 15.29 & 220.1 & 0.70 \\
\hline $\begin{array}{l}\text { Fernandes et } \\
\text { al. (2009) }\end{array}$ & 6.75 & 15.91 & 13.20 & 7.20 & 2.28 & 9.01 & 12.17 & 10.63 & 62.2 & 0.59 \\
\hline $\begin{array}{l}\text { Fernandes et } \\
\text { al. }(2000)\end{array}$ & 3.36 & 6.87 & 5.88 & 3.55 & 1.36 & 4.28 & 5.59 & 4.91 & 5.48 & $\begin{array}{c}- \\
0.11\end{array}$ \\
\hline Nelson (1980) & 4.46 & 9.81 & 8.26 & 4.73 & 1.64 & 5.82 & 7.67 & 6.77 & 11.12 & 0.18 \\
\hline $\begin{array}{l}\text { Nelson and } \\
\text { Adkins (1986) }\end{array}$ & 4.48 & 9.74 & 8.23 & 4.75 & 1.67 & 5.82 & 7.64 & 6.76 & 10.81 & 0.18 \\
\hline $\begin{array}{l}\text { Van Wilgen } \\
\text { (1986) }\end{array}$ & 5.23 & 11.76 & 9.86 & 5.57 & 1.88 & 6.87 & 9.13 & 8.03 & 24.03 & 0.34 \\
\hline $\begin{array}{l}\text { Vega et al. } \\
\text { (1998) }\end{array}$ & 8.20 & 17.84 & 15.06 & 8.70 & 3.07 & 10.66 & 13.99 & 12.38 & 87.4 & 0.74 \\
\hline
\end{tabular}

With regard to flame length models, four models are quite adequate to predict flame length in the Kogelberg (Table 2) and the Cederberg experiments (Table 3). These data are accurately fitted with the empirical relationships proposed by Fernandes', Nelson's, Nelson and Adkins's laws and by the physical model too.

Empirical laws are useful to quantify flame length but should not be used to compare fires in fuel types, which are structurally very different (Morvan et al., 2002). Besides, really hazardous fires, such as those burning under conditions of strong wind at the field scale, cannot be properly quantified because of the contribution of heat convection to the heat transport ahead of the flame front. Moreover, empirical laws are not predicted. It is a strong argument for a physical approach. So, a physical simplified approach is applied to obtain an analytical expression of the flame length.

\subsection{Comparison of the results given by the mobile application on various vegetation types}

This section deals with the computation of Acceptable Safety Distances in which a fire spreads across five different fuels in the Mediterranean area (the intrinsic characteristics of each fuel are detailed in table 1). Two wind speed values are randomly chosen $\left(3\right.$ and $\left.5 \mathrm{~m} \cdot \mathrm{s}^{-1}\right)$. Table 4 presents the ASD obtained with the rule-of-thumb stated by Butler and Cohen (1998) and the physical model presented in section two. 
Table 4. Comparison of the ASD values (m) obtained with a rule-of-thumb, applied to five different fuels in the Mediterranean.

\begin{tabular}{cccccc}
\hline Wind (m.s-1) & $\begin{array}{c}\text { Corsican tall } \\
\text { shrub }\end{array}$ & $\begin{array}{c}\text { Corsican } \\
\text { shrub }\end{array}$ & $\begin{array}{c}\text { Sardinian } \\
\text { shrub (type 1) }\end{array}$ & $\begin{array}{c}\text { Sardinian } \\
\text { shrub (type 2) }\end{array}$ & grassland \\
\hline 3 & 10.14 & 11.16 & 11.05 & 10.48 & 8.86 \\
\hline 5 & 14.87 & 16.06 & 20.46 & 15.32 & 14.37 \\
\hline
\end{tabular}

If the values of ASD are similar for a $3 \mathrm{~m} . \mathrm{s}^{-1}$ wind speed whatever the fuel bed, they are quite different when the wind speed increases. As the physical model (especially the flame length sub-model) gives a good precision (see the errors given in tables 2 and 3), it is necessary to have either accurate characteristics of the vegetal stratum or a good modelling for an equivalent fuel.

\subsection{Graphical user interface}

ASD results provided by our Web Service are useful for firefighters on field when evaluating distances for fuelbreak, the client side must then provide a clear GUI to visualize the terrain and our results, an unobtrusive way to feed input data and a way to retry computations in case of a network failure. In order to fit such requirements, the client has been implemented as a mobile application on both iOS and Android platforms and designed to run primarily on tablets. The results presented are from iOS client. The application is in French. The user interface will be essentially composed of:

(1) a sliding panel on the left side providing a section containing a list of previous cached computations and the ability to create a new one. Another section is there for configuration purposes. This menu is shown in Figure 3.a, it also allows you to select a fuel types (Corsican tall shrub, Corsican shrub, Sardinian shrub (type 1), Sardinian shrub (type 2), grassland), or configure a local wind;

(2) a map fitting the whole screen and representing the current selected computation. The map contains the user location if available; the path for which we want the results and when these are available, the ASD zone is drawn as a polygon. The user can touch the zone to display detailed information about results (Figure 3.b);

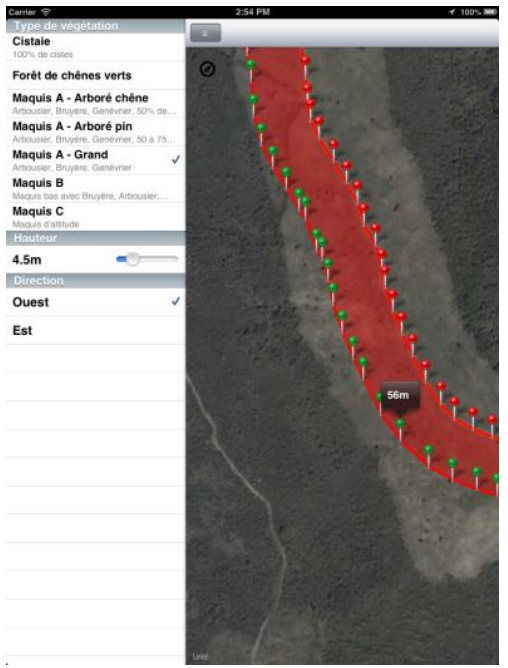

(a) left menu

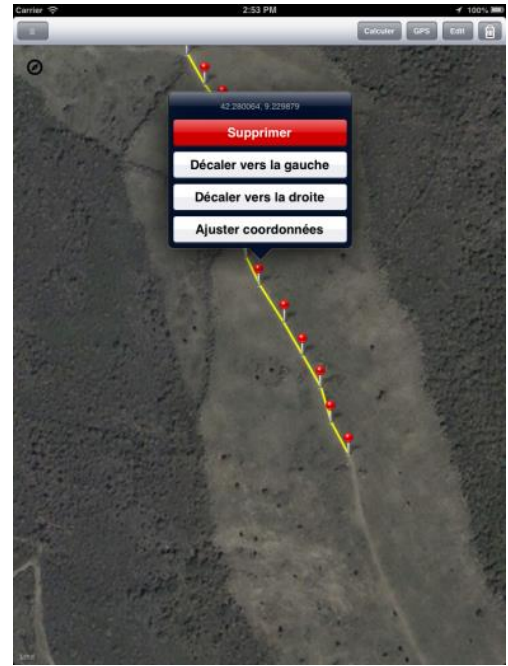

(b) drawing the path

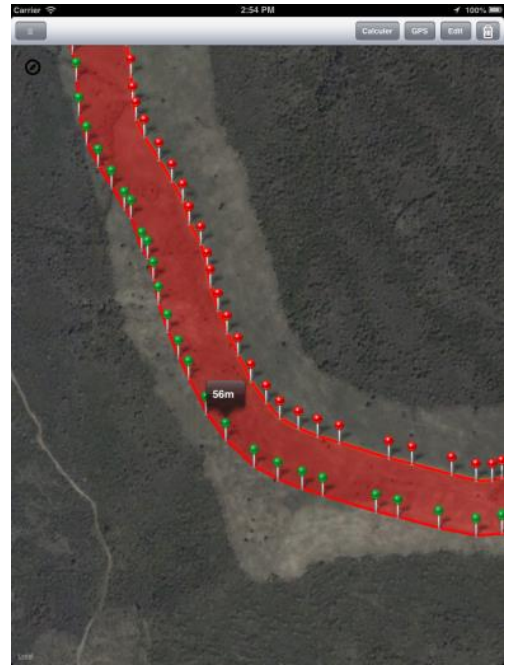

(c) result

Figure 3. Display example.

(3) the map has three distinct modes: the normal mode, the user-tracking mode and the drawing mode. Each of these are detailed respectively below : (3.1) the normal mode displays all available data for the current selected computation and allows user interaction to show detailed information; (3.2) since our Web Service input is essentially a set of coordinates, these GPS enabled devices allow us to provide 
a handy user-tracking mode. Thereby, as the user location is updated we can spawn requests to our Web Service and draw a polygon that will represent the ASD; (3.3) finally, the drawing mode allows the user to place a set of locations directly on the terrain and adjust each of them. The final result is shown in Figure 3. We can see the contours of the safety zone.

\section{Conclusions}

This paper presents a multidisciplinary work and argues a software tool to compute Acceptable Safety Distance (ASD). This distance was usually set thanks to a general rule-of-thumb: it should be at least 4 times the maximum flame length. This distance is very important because it is used to design fuel breaks. In our approach, to quantify the fireline intensity, a closed physical model is used. The model is hosted as a web service, and used a simulation framework based on Discrete EVent system Specification formalism (DEVS). In this new work, we present various results based on the vegetation characterization.

One goal of this study is to provide an accurate quantification of a safety zone at the field scale. To quantify this area different flame models (one simplified physical model and twelve empirical correlations) are tested using several experiments. Model predictions are compared against measured flame length of spreading fires through shrub vegetation. This work shows that the simplified physical approach presents a main advantage: its capability to be used for all types of fires under a wide range of conditions if fuel models, describing structural types of vegetation, are available. So, this model can be seen as an alternative operational length flame model, which can be applied to calculate more accurately safety distances.

Now, as expected fire-fighters, we will now turn our application on desktop.

\section{References}

Al-Zoubi K., Wainer G. (2009) Using REST Web-Services Architecture for Distributed Simulation, Principles of Advanced and Distributed Simulation, PADS'09. ACM/IEEE/SCS 23rd Workshop, June 22-25, pp 114-121, doi:10.1109/PADS.2009.16

Balbi J.H., Rossi J.L., Marcelli T., Santoni P.A. (2007) A 3D physical real-time model of surface fires across fuel beds, Combustion Science and Technology, 179:12, 2511-2537.

Balbi J.H., Morandini F., Silvani X., Filippi J.B., Rinieri F. (2009) A physical model for wildland fires, Combustion and Flame, 156, 2217-2230.

Balbi J.H., Rossi J.L., Marcelli T., Chatelon F.J. (2010) Physical modeling of surface fire under nonparallel wind and slope conditions, Combustion Science and Technology, 182, 922-939.

Bisgambiglia P.-A., Filippi J.B., De Gentili E. (2006) A fuzzy approach of modelling evolutionary interfaces systems, In 'Proceedings of the ISEIM 2006 (IEEE eds)', Corte, France, 98-103.

Bisgambiglia P.-A., Franceschini R., Chatelon F.J., Rossi J.L., Bisgambiglia P. (2013) Discrete Event Formalism To Calculate Acceptable Safety Distance, In "proceedings of the 2013 Winter Simulation Conference (Pasupathy R., Kim S.-H., Tolk A., Hill R. and Kuhl M.E. Eds), Washington DC, USA, pp 217-228.

Burrows, J.K. (1994) Experimental development of a fire management model for jarrah (Eucalyptus marginata Donn ex Sm) forest. PhD thesis, Australian National University, Canberra.

Butler, B.W, Cohen, J.D.; 1998. Firefighter Safety Zones: A Theoretical Model Based on Radiative Heating. International Journal of Wildland Fire. 8(2), 73-77.

Butler, B.W., Finney, M.A., Andrews, P.L., Albini, F.A., (2004) A radiation-driven model of crown fire spread. Canadian Journal of Forest Research, 34, 1588-1599.

Byram, G.M., (1959) Combustion of forest fuels, in: Davis, K. P. (Eds.), Forest Fire: Control and Use, McGraw_Hill, New-York, pp. 61-80. 
Catchpole, W.R., Bradstock, R.A., Choate, J., Fogarty, L.G., Gellie, N., McCarthy, G., McCaw, W.L., Marsden-Smedley, J.B., Pearce, G., (1998). Cooperative development of equations for healthland fire behavior, in Viegas, D.X. (Eds.), in Proceedings 3rd International Conference on Forest Fire Research and 14th Conference on Fire and Forest Meteorology, Coimbra, pp. 631-645.

Clark, R.G., (1983) Threshold requirements for fire spread in grassland fuels. PhD thesis, Texas Tech. University, Lubbock.

Fernandes, P.M., Catchpole, W.R., Rego, F.C., (2000) Shrubland fire behavior modeling with microplat data. Canadian Journal of Forest Research, 30, 889-899.

Fernandes, P.M., Botelho, H.S., Rego, F.C., Loureiro C., (2009) Empirical modeling of surface fire behavior in maritime pine stands. International Journal of Wildland Fire. 18, 698-710.

Franceschini R., Bisgambiglia P.-A., Bisgambiglia P.A., Hill D.R.C. (2014) DEVS-Ruby: a Domain Specific Language for DEVS Modeling and Simulation (WIP), In 'proceedings of the symposium on Theory of Modeling \& Simulation', DEVS Integrative M\&S Symposium, Tampa, Florida, USA.

Green L.R., Schimke H.E. (1971) Guides for fuel-breaks in the Sierra Nevada mixed-conifer type, Berkeley, California, USDA Forest Service, Pacific SW, Forest and Range Experimental Station.

Harzallah Y., Michel V., Liu Q., Wainer G. (2008) Distributed Simulation and Web Map Mash-Up for Forest Fire Spread, Services - Part I, IEEE Congress on, pp 176-183, doi:10.1109/SERVICES1.2008.74.

Innocenti E., Silvani X., Muzy A., Hill D.R.C. (2009) A software framework for fine grain parallelization of cellular models with OpenMP: Application to fire spread, Environmental Modeling and Sofware, 24(7), 819-831.

Kim K.-H., Kang W.-S. (2005) A web services-based distributed simulation architecture for hierarchical DEVS models, In 'Proceedings of the 13th international conference on AI, Simulation and Planning in High Autonomy Systems', Berlin, Heidelberg, pp 370-379.

Marcelli T., Balbi J.H., Moretti B., Rossi J.L. Chatelon F.J. (2011) Flame height model of a spreading surface fire, In "proceedings of the seventh Mediterranean Combustion Symposium", September 11-15, Chia Laguna, Cagliari, Italy, 2011.

Mittal S., Risco J.L., Ziegler B.P. (2007) DEVS-Based simulation web services for net-centril T\&E, In 'proceedings of the 2007 Summer Computer Simulation Conference', San Diego, California, USA, pp 357-366.

Morvan D., Tauleigne V., Dupuy J.L. (2002) Flame geometry and surface to crown fire transition during the propagation of a line fire through a Mediterranean shrub, In 'Proceedings of the fourth International Conference on Forest Fire Research and Wildland Fire Safety (Ed. D.X. Viegas)', Luso-Coimbra, Portugal, November 16-20, CD-ROM, ADAI, Millpress:Rotterdam.

Muzy A., Innocenti E., Aïello A., Santucci J.F., Santoni P.A., Hill D.R.C. (2005) Modelling and simulation of ecological propagation processes: application to fire spread, Environmental Modelling and Sofware, 20(7), 827-842.

Nader B., Filippi J.-B., Bisgambiglia P.-A. (2011) An experimental frame for the simulation of forest fire spread, In "proceedings of the 2011 Winter Simulation Conference", pp 1010-1022.

Nelson, R.M. Jr., (1980) Flame characteristics for fires in southern fuels. U.S.D.A. Forest Service, General Research Paper SE-205. Southeast. Forest Experimental Station, Asheville, NC, USA.

Nelson, R.M. Jr. and Adkins, C.A., (1986) Flame characteristics of wind-driven surface fires. Canadian Journal of Forest Research. 16, 1293-1300.

Ntaimo L., Hu X., Sun Y. (2008) DEVS-FIRE: Towards an Integrated Simulation Environment for Surface Wildfire Spread and Containment, Simulation, 84(4), 137-155.

Ntaimo L., Ziegler B.P., Vasconcelos J., Khargharia B. (2004) Forest Fire Spread and Suppression in DEVS, Simulation, 80(10), 479-500.

Van Wilgen B., Le Maitre D.C., Kruger F.J. (1985) Fire behaviour in South African fynbos (Macchia) vegetation and predictions from Rothermel's fire model, Journal of Applied Ecology,22(1), $207-$ 216. 
Vega, J.A., Cuinas, P., Fonturbel, T., Perez-Gorostiaga, P., Fernandez, C., (1998) Predicting fire behavior in Galician (NW Spain) shrubland fuel complexes, in Proceedings 3rd International Conference on Forest Fire Research and 14th Conference on Fire and Forest Meteorology, Coimbra, pp. 713-728.

Wainer G.A., Madhoun R., Al-Zoubi K. (2008) Distributed simulation of DEVS and Cell-DEVS models in CD++ using Web-Services, Simulation Modeling Practice and Theory, 16(9), 1266-1292.

Ziegler B.P., Praehofer H., Kim T.G. (2000) Theory of Modeling and Simulation, Second Edition.

Ziegler B.P. (2005) Discrete Event Abstraction: An emerging paradigm for modelling complex adaptative systems, In 'Perspectives on Adaptation in Natural and Artificial Systems Chapter 6 (Booker L., Forrest S., Mitchell M., Riolo R. eds)', Oxford, England, New York: Oxford University Press. 